\title{
The Development of Uberization Processes in an Innovative Economy: Models and Principles of Marketplace Organization
}

\author{
Mariya A. Gurina, Yuliya V. Rumyantseva, Valery V. Chernyaev, Yuriy I. Yacuhin,
}

\begin{abstract}
The article discusses one of the main trends in the development of electronic commerce since 2016 - Uberization, the basis of which are marketplaces. According to the authors, the use of a business Uberization model obliges the company to change the process of interaction with contractors by implementing information technologies, developing its own information platform and mobile application for direct communication between buyers and sellers.

The article reveals the position that in the global economy the marketplace technology is becoming increasingly relevant for a large number of industries, as this is a simple way to expand the range without increasing costs. Model variations are considered in detail and an overview of global and Russian marketplaces is provided: $C 2 C, B 2 C$ and $B 2 B$. The analysis of the Russian market of online trading and the development of marketplaces is carried out. The authors conclude that the Russian market is somewhat behind the world market, however, the speed and scale of the spread of this technology are gaining momentum.

The article analyzes the trends in the development of the uberization business model of Russian companies, assesses the advantages of its use - large electronic trading platforms, increasing their volume of activity, set the market standard for online trading for consumers, which leads to accustomation and increases the frequency of orders of the average consumer. In addition to aggregating a large number of offers, expanding the assortment and reducing costs for all market participants, marketplaces allow monitoring competitors: their volumes, assortment, pricing and subjective assessment of the work of each company.
\end{abstract}

Key words: innovative economy, uberization business model, marketplaces.

\section{INTRODUCTION}

The most difficult problem of leading world companies today is the management of technological innovation [9] .

Revised Manuscript Received on November 05, 2019.

Mariya A. Gurina, $\mathrm{PhD}$ in Economics, associate professor, mariyagurina2018@gmail.com

Public, municipal service and management department, Russian Presidential Academy of National Economy and Public Administration, Lipetsk branch, 398000, Russia.

Yuliya V. Rumyantseva, $\mathrm{PhD}$ in Economics, associate professor, 1stu@gmail.com

Management department Lipetsk State Technical University Lipetsk, 398000, Russia.

Valery V. Chernyaev, $\mathrm{PhD}$ in Economics, professor, valeriy.chernyaev@mail.ru

Public, municipal service and management department, Russian Presidential Academy of National Economy and Public Administration, Lipetsk branch, 398000, Russia.

Yuriy I. Yacuhin, Ph.D. in Sociology, associate professor, mag30@mail.ru

Public, municipal service and management department, Russian Presidential Academy of National Economy and Public Administration, Lipetsk branch, 398000, Russia.
An innovative economy develops in a complex, uncertain and global environment and is faced with the rapid obsolescence of information and a shorter product life cycle.

A special role in the development of trends in the modern economy is played by the accessibility to the Internet, services, applications and the spread of various electronic platforms (grocery, service market, social, platform content forms).The most epitome of a breakthrough of such platforms in terms of their power and one of the main trends in the development of electronic commerce since 2016 is the Uber model or Uberization [12]. This term comes from the name of the American company Uber, which in 2009 developed a mobile application for searching, calling and paying for taxis. The Uber application allows you to create travel requests that are directly redirected to drivers registered in the system [11].

In earlier studies, we wrote in detail about the content, structure and risks of the uberization business model [6]. The uberization model of the economy is a modern trend, which is a promising and cardinal replacement for the existing system of economic relations of counterparties that has been developed in previous technological systems. The use of uberization business model obliges the company to change the process of interaction with contractors by implementing information technologies, developing its own information platform and mobile application for direct communication between buyers and sellers. The interaction within the framework of uberization is shown in Figure 1. 


\section{The Development of Uberization Processes in an Innovative Economy: Models and Principles of Marketplace Organization}

Uber company provides a platform and mediation services: customer search and information provision; cost calculation and transaction; coordination of actions to complete the transaction, communication between counterparties; quality control of performance; settlement between counterparties

The supplier of goods or services places its offer of goods or services, receives payment upon the successful completion of the transaction

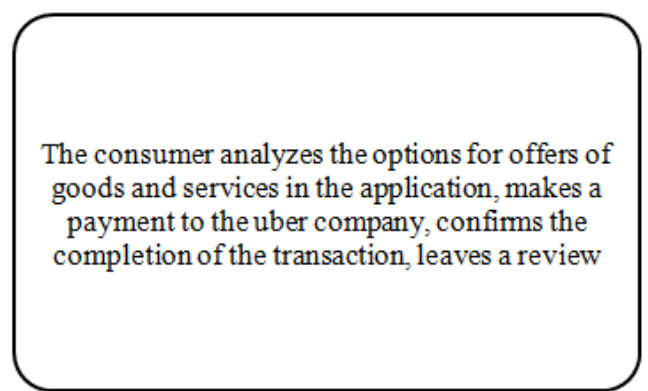

Figure 1: Marketplaces in the structure of the uberization business model

The basis of the uberization business model is the marketplace. Marketplace is an information intermediary between sellers and potential customers, who in one place can select and compare offers, is acquainted with product reviews. Essentially, a marketplace is the same market, but in an online environment. The significance of the role, principles of organization and use cases in the modern world and Russian economy is dedicated to our research.

\section{APPROACHES TO CLASSIFICATION AND COMPARATIVE ANALYSIS OF THE MODELS IN THE STRUCTURE OF AN UBERIZATION BUSINESS MODEL}

In the global economy, marketplace technology is becoming increasingly relevant for a large number of industries, as this is a simple way to expand the assortment without increasing costs. As world practice shows, most of the companies that become marketplaces are e-commerce players, large retailers, postal and logistics operators, financial organizations, as well as IT companies [2]. The development of an urbization model based on the use of marketplaces leads to the expansion of outlets, logistics opportunities and an increase in the client base.

In our article we will take a closer look at the variations of the models and give an overview of world and Russian marketplaces: C2C, B2C and B2B.

$\mathrm{C} 2 \mathrm{C}$-marketplace assumes that all participants in transactions are individuals. They may have similar interests, wealth, age, use joint agreements for the purpose of general economy, and change the roles of buyers and sellers. An example of a $\mathrm{C} 2 \mathrm{C}$ marketplace in order to save

money is the BlaBlaCar service. In the literature, the concept of a "sharing economy" is used, which involves the interaction of counterparties not for the purpose of earning, but for the purpose of joint savings. An example of a C2C marketplace as a community of like-minded people is the Couchsurfing service for travelers. Service users have the opportunity to stay for free for the night and get a hot dinner in any city in the world. Communities can have a different focus: handmade products (Etsy), pets (DogVacay), etc Examples of $\mathrm{C} 2 \mathrm{C}$ marketplace using role switching: SkillShare (online training), Preply (search for tutors), Avito.ru (posting ads for the sale of goods and services), Avto.ru (posting ads for selling cars), etc. In all of these In cases, it is possible for the same individual to act as both a seller and a buyer of products.

B2C-marketplace involves the interaction of a business (legal entities) with potential customers (individuals). The main goal and advantage of such electronic platforms is a wide range of commercial offers on one site. In American sources there is the concept of "one stop shop", i.e. point of sale where you can buy all types of products of interest. The largest and most well-known representative of B2Cmarketplace - AliExpress service - an enormous in terms of scale and income electronic trading platform on which sellers display their goods. On average, more than 525 million people use the service. per month.

B2B-marketplaces are based on the sale of products of some firms (legal entities) to others. The same Alibaba service allows you to make bulk purchases for the business.

A comparative analysis

of $\mathrm{C} 2 \mathrm{C}, \mathrm{B} 2 \mathrm{C}$ and $\mathrm{B} 2 \mathrm{~B}$ 
models is presented in table 1 .

Table 1: Comparative analysis of marketplace models [14]

\begin{tabular}{|c|c|c|c|}
\hline Factors & $\mathrm{C} 2 \mathrm{C}$ & $\mathrm{B} 2 \mathrm{C}$ & $\mathrm{B} 2 \mathrm{~B}$ \\
\hline Cost of services & tens of dollars & Tens or hundreds of dollars & Thousands or millions of dollars \\
\hline Prices & Negotiable & Standard market & $\begin{array}{c}\text { Agreed with the client depending } \\
\text { on the order Agreed with the client } \\
\text { depending on the order }\end{array}$ \\
\hline $\begin{array}{l}\text { Duration of the purchase process } \\
\text { for the user }\end{array}$ & $\begin{array}{c}\text { From a couple of hours to several } \\
\text { days }\end{array}$ & $\begin{array}{l}\text { From a couple of days to several } \\
\text { weeks }\end{array}$ & $\begin{array}{c}\text { From several days to several } \\
\text { months }\end{array}$ \\
\hline How many people decide to buy & One or two & One or two & Group of people up to 12 people. \\
\hline $\begin{array}{l}\text { The complexity of the purchase } \\
\text { process for the user }\end{array}$ & $\begin{array}{l}\text { Simple enough, price is discussed, } \\
\text { delivery and payment options }\end{array}$ & $\begin{array}{c}\text { Relatively simple, price, payment, } \\
\text { delivery options are discussed, but } \\
\text { less often }\end{array}$ & $\begin{array}{c}\text { Complicated, lengthy negotiations } \\
\text { over the price: all points are } \\
\text { discussed up to guarantees }\end{array}$ \\
\hline What motivates the buyer & Individual needs and emotions & Individual needs and emotions & Business needs \\
\hline $\begin{array}{l}\text { The complexity of the registration } \\
\text { process for providers }\end{array}$ & Simply & Medium & Complicated \\
\hline $\begin{array}{l}\text { The main objectives of } \\
\text { marketplaces }\end{array}$ & $\begin{array}{l}\text { Introduce a product / service; } \\
\text { present a solution to a problem; } \\
\text { create user community }\end{array}$ & $\begin{array}{l}\text { Show a wide range of goods and } \\
\text { services; } \\
\text { to introduce the brands; } \\
\text { create conditions for competition } \\
\text { (more reliable, more comfortable, } \\
\text { faster) }\end{array}$ & $\begin{array}{l}\text { Offer a solution for a business; } \\
\text { sell to large players; } \\
\text { be the first in your niche }\end{array}$ \\
\hline Niches that feature marketplaces & $\begin{array}{l}\text { Public flea markets, personal } \\
\text { services }\end{array}$ & Retail trade (goods and services) & $\begin{array}{c}\text { Direct deliveries, services, } \\
\text { wholesale }\end{array}$ \\
\hline
\end{tabular}

As an example, we can cite the following companies that use marketplaces in the structure of the uberization business model (Table 2).

Table 2: Examples of companies using marketplaces (by type)

\begin{tabular}{|c|c|c|}
\hline C2C & B2C & B2B \\
\hline BlaBlaCar & AliExpress & Alibaba.com \\
Olx & Booking.com & Indiamart \\
Etsy & Amazon & Capterra \\
Couchsurfing & GoldenLine & \\
DogVacay & Zocdoc & \\
SKILLSHARE & & \\
Preply & & \\
Craigslist & & \\
\hline
\end{tabular}

Another classification of marketplaces is the division into categories of goods and services into the following groups:

- goods;

- services;

- information;

- investments and crowdfunding.

Table 3 presents the companies using marketplaces in accordance with this classification.

Table 3: Examples of companies using marketplaces (by categories of goods and services)

\begin{tabular}{|c|c|c|c|}
\hline Information & Goods & Services & Investment \& fundraising \\
\hline Twitch & eBay & Uber & KircksteUp \\
Soundcloud & Amazon & Airbnb & Indiegogo \\
YouTube & Etsy & Booking.com & \\
Yelp & Couchsurfing & \\
Spotify & DogVacay & \\
& Apple Play & & \\
\hline
\end{tabular}

The product category is the largest: here are Chinese AliExpress, and American eBay, and Russian Wildberries, Ozon and others. Even Apple and Android app stores are also marketplaces. For the B2B sector, Alibaba and Allbiz are popular marketplaces, the rest are narrowprofile, for specific groups of products. An interesting project was the Beru goods marketplace, a joint development of Yandex.Market and Sberbank. The terms of use of the platform are quite transparent, for suppliers there is a reference section with documentation. Information marketplaces include YouTube, Soundcloud and Spotify, where many users can share content and view / listen to it. The investment portal and fundraising include the foreign portal for crowdfunding Kickstarter and the Russian counterpart Planeta.ru, as well as the Indiegogo marketplace, where people sell their own products.

\section{THE ADVANTAGES OF MARKETPLACES AND PROSPECTS FOR THE DEVELOPMENT OF THE RUSSIAN ONLINE TRADING MARKET}

The Russian market of online trading and the development of marketplaces is somewhat behind the global one, however, the speed and scale of the spread of this technology are gaining momentum. The share of online commerce in Russia

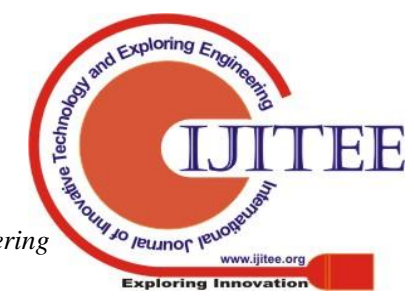




\section{The Development of Uberization Processes in an Innovative Economy: Models and Principles of Marketplace Organization}

has grown: in 2017 it amounted to $2.8 \%$, at the moment $3 \%$.

Data Insight presented the main results of the Russian e-commerce market for the I half of 2019 [15]:

- the number of orders - 191 million (almost the same for the entire 2016);

- an increase in the number of orders - $44 \%$ (a record for the entire time of observation) to the similar period of 2018

- change in the average check - minus $13 \%$ (the check is reduced on average throughout the Russian market, but is heterogeneous, orders are becoming more frequent and smaller) by the same period in 2018 ;

- volume of orders (market capacity) 725 billion rubles;

- the increase in volume is $26 \%$.

Among the main trends is the active growth of market leaders: Wildberries, Ozon and Pharmacy.ru. The total growth in sales of leaders amounted to $107 \%$ compared to the first half of 2018, in 2016-2017. over the same period, the increase was $37 \%$. The number of points for issuing Wildberries orders by September 2019 was 5,000, while at the end of 2018 there were 1,600 . The share of online sales of Wildberries in the first half of 2019 was $31 \%$ of the total number of orders. In monetary terms, the share of Wildberries is less, since the company has an average check below the market. Ozon also increased the frequency of orders by increasing the number of points of issue of orders and simplifying delivery by premium subscription. The growth of the Ozon marketplace has become a driver for the entire e-commerce market in Russia.

The general development tendency of the uberization business model of Russian companies is such that large electronic trading platforms, increasing their volumes of activity, set the market standard for online trading for consumers, which leads to accustomation and increases the frequency of orders of the average consumer. Over the past four years, the share of pickup has been increasing, which also leads to a decrease in the average bill.

In 2018, the Russian online trading market size was:

- 301 million parcels;

- $\quad 1.3$ trillion. rub.;

- the growth by 2017 amounted to $28 \%$ in parcels, $22 \%$ in monetary terms.

The intensification of the marketing efforts of marketplaces received a response from customers who have gained experience in foreign online shopping and trust in them. If in the market as a whole, the number of online orders for the I half of 2019 increased by 59 million units. compared to the same period in 2018, the three fast-growing projects - Wildberries, Ozon and Pharmacy.ru - added 43 million orders, or $73 \%$ of the total increase. Tens of millions of customers are quickly becoming accustomed to online purchases through the accumulation of experience and standardization of the purchase process by market leaders. This tendency to accelerate the growth of online commerce will presumably continue in the next few years - such data was obtained by the comprehensive Data Insight methodology, based on the analysis of the number of online orders in Russian online stores, web statistics

A comparative analysis of known marketplaces is given in table 4.

Table 4: Parameters of some well-known marketplaces [14]

\begin{tabular}{|c|c|c|c|c|c|c|}
\hline Parameters & Beru & Ozon & Goods & Wildberries & Ulmart & Alibaba \\
\hline audience & No data & $\begin{array}{c}\text { up to } 1.2 \\
\text { million people }\end{array}$ & No data & $\begin{array}{c}2 \text { million } \\
\text { people a day }\end{array}$ & $\begin{array}{c}500 \text { thousand } \\
\text { people per } \\
\text { day }\end{array}$ & $\begin{array}{l}525 \text { million } \\
\text { people per } \\
\text { month }\end{array}$ \\
\hline $\begin{array}{c}\text { Number of } \\
\text { partners }\end{array}$ & 1000 & No data & 300 online stores & 10500 brands & No data & No data \\
\hline Categories & $>600$ & $>20$ & $\begin{array}{c}14 \text { major and }>100 \\
\text { subcategories }\end{array}$ & 12 & $>6000$ & $>40$ \\
\hline $\begin{array}{l}\text { Cities and own } \\
\text { distribution } \\
\text { points }\end{array}$ & $\begin{array}{c}\text { Delivery in Russia of } \\
\text { CDEK and DPD, no } \\
\text { own POD }\end{array}$ & $\begin{array}{c}\text { 1086 POD in } \\
\text { Russia }\end{array}$ & $\begin{array}{l}\text { Moscow and the } \\
\text { region, St. } \\
\text { Petersburg and the } \\
\text { region, since } 2019 \text { - } \\
\text { in cities with over } \\
\text { one million people }\end{array}$ & $\begin{array}{l}2107 \text { POD in } \\
\text { Russia }\end{array}$ & $\begin{array}{l}240 \text { cities of } \\
\text { Russia, } 1000 \\
\text { POD }\end{array}$ & $\begin{array}{l}190 \text { countries of } \\
\text { the world, } \\
\text { delivery by mail } \\
\text { or logistics } \\
\text { companies, } \\
\text { there are no own } \\
\text { POD }\end{array}$ \\
\hline Fee & $2-11 \%$ & до $18 \%$ & $\begin{array}{c}\text { Depending on } \\
\text { average prices, } \\
\text { margin and category }\end{array}$ & No data & No data & No data \\
\hline $\begin{array}{l}\text { Registration } \\
\text { Parameters }\end{array}$ & $\begin{array}{l}\text { Fill out the form and } \\
\text { attach the product } \\
\text { catalog in table format }\end{array}$ & $\begin{array}{l}\text { Fill out the } \\
\text { form and } \\
\text { connect the } \\
\text { client (create an } \\
\text { account) }\end{array}$ & $\begin{array}{l}\text { Fill out the form and } \\
\text { post a link to the } \\
\text { xml-file with } \\
\text { updated product } \\
\text { offers }\end{array}$ & No data & $\begin{array}{l}\text { Fill out the } \\
\text { form and } \\
\text { select } \\
\text { product } \\
\text { categories }\end{array}$ & $\begin{array}{l}\text { Fill out a step- } \\
\text { by-step email- } \\
\text { linked form }\end{array}$ \\
\hline
\end{tabular}

We examined the parameters of some of the largest marketplaces, but in addition to them, there are about 60 that can be narrow-profile and niche. Creation of a marketplace is a normal development for a company that has outgrown the format of an online store and is ready to expand its range by attracting suppliers.

The use of Internet sites as part of an uberization business model has several advantages. In addition to aggregating a large number of proposals, expanding the assortment, reducing costs for all market participants, marketplaces allow monitoring competitors: their volumes, assortment, pricing and subjective assessment of the work of each company.

A positive feature of marketplaces is the ability to systematize information about products - the user only has to choose from the myriad of offers that will appeal more than others. Marketplaces are created in a variety of areas from hotel reservations and search for airline tickets to medicine and finance - which proves the effectiveness of the proposed business model. 
If we summarize the possibilities and advantages of Internet sites for all market participants, we can distinguish the following:

- maximum benefit to owners, suppliers and buyers in the context of the range, prices, information;

- a differentiated approach to different customers due to paid and free options for the provision of services, use of catalogs, obtaining information, posting your requests and announcements. For example, the HeadHunter job search portal is arranged: job seekers post their resumes for free, and companies pay for access to their resume and the opportunity to invite interesting candidates for interviews;

- equal opportunities for different market players, gaining access to the trade of small business participants, which is very relevant in conditions of high administrative barriers in Russia; participants;

- Possibilities of integration with other marketplace

- Digitalization in the context of the development of marketplaces increases the importance of ordinary customers;

- the possibility of using integrated solutions to achieve the best results at the lowest price (to ensure customer loyalty, companies have to team up with other market participants to give the client maximum convenience of use and consumption);

- the development of partnerships provides an opportunity for consolidated strengthening in the market positions of all players;

- the ability to form a high level of trust in the seller through open reviews and ratings with the continued relevance of brand status.

The study of electronic platforms poses a question for specialists about the need to distinguish between such concepts as marketplace, aggregator and online store.

We believe that not every online store can be called a marketplace, but conditionally each marketplace can be called an aggregator. Aggregator site is a site that contains offers from many manufacturers and suppliers. If manufacturers and suppliers place goods on the site of a multi-brand online store and pay its owner a commission on each sale, such an online store can be called both an aggregator and a market place. If the online store presents goods from only one seller, who simultaneously owns this online store, this is not a marketplace, but a branded online store. If the store owner purchases goods of other brands for independent online sale, then this is the format of a multibrand online store.

The main features of the marketplace include:

- the ability to register as a partner;

- the need for the supplier to pay a commission for each transaction;

- the ability to immediately make a purchase, aggregation of physical goods in the warehouse of the marketplace (preferably). For example, Yandex.Market itself, although it is referred to as marketplace, is not one, because you cannot make a purchase through the service. Inside the goods on Yandex.Market contains only a link to the supplier's website. You will have to go to the website of the supplier or manufacturer and follow its instructions. But the joint project of Yandex and Sberbank "Beru" meets this criterion, therefore it is a market place.

Since 01/01/2019, new legislative rules have been issued: now each aggregator site must indicate full information about the supplier of a product or service (company name, name of the contractor, operating mode, address, PSRN / PSRN). In addition, you need to be prepared to compensate for losses due to the placement of inaccurate information or return the prepayment if the goods / service were not provided to the client on time. Another possible legislative measure - increase of duties on purchases in foreign online stores - can indirectly be called to make Russian online trading more competitive. Some countries have already taken this route. According to some experts, from January 1, 2019 in Russia the threshold for duty-free import was reduced from $€ 1000$ to $€ 500$, by 2020 it will become even lower - $€ 200$ [14].

\section{CONCLUSIONS}

Summing up our small study, it should be noted that the Russian economy has entered an active phase in the development of processes of uberization, in which startups based on a digital platform connect private clients and enterprises. Over the past few years, there has been a rapid increase in the number of Internet sites in various business fields. A comparative analysis of the famous marketplaces revealed a large number of growing electronic platforms in Russia, which provide significant advantages to all participants in the relationship. Reducing transaction costs of customers by optimizing the economic value chains in real time; a unified approach to all participants of the "uber service" is organized, which balances the interests of independent market agents; the process is automated by eliminating human participation, digitalization leads to the integration and development of partnerships, as well as transparency of market relations.

In addition to the obvious advantages, electronic platforms have problem areas and disadvantages that need to be taken into account by Russian companies wishing to be in the trend of electronic commerce. First of all, it is the need to create a unique selling proposition that will explain why your marketplace is better than the others, and a hidden advantage that cannot be copied. Another problem in creating a marketplace is the need to answer questions about target customers and their needs, channels for attracting users, about a business model, revenue generation and cost structure. There is a possibility of unscrupulous and unreliable suppliers appearing on the site, and the problem of having a large solvent audience to form a customer base remains.

At the same time, Russian companies, pragmatically and thoughtfully introducing technological innovations such as marketplaces, are becoming leaders of change. Changes in the structure of management activities based on digital technologies and the uberization model allow companies, including Russian ones, to implement breakthrough innovative approaches to management.

\section{REFERENCES:}

1. Website for informational messages of ROSBUSINESSKON SALTING JSC: Alibaba. [Electronic resource] URL: https://quote.rbc.ru/company/1021 (In Russian)

2. Alstyne M., Parker G., Choudary S. (2017). Platform revolution. New York: Norton \& Company.

3. Bakharev I. The largest marketplaces of Russia: analytics SimiliarWeb. [Electronic resource] URL: https: // EPEPPER/ (In Russian) 


\section{The Development of Uberization Processes in an Innovative Economy: Models and Principles of Marketplace Organization}

4. Chesbrough H. (2006). Open Innovation: The New Imperative for Creating and Profiting from Technology. Harvard Business Press.

5. Glazacheva T. (2019) Marketplaces of Russia: how they work and in what direction they are developing? [Electronic resource] URL: https://www.retail-loyalty.org/expert-forum/ (In Russian)

6. Gurina M.A., Rumyantseva Yu.V. System challenges of the fourth industrial revolution: Uberization as a new business model // Issues of innovative economy. - 2019. - V. 9. - No. 3. (In Russian)

7. Khosrow-Pour, D.B.A., Mehdi - editor. (2018) Advanced Methodologies and Technologies in Digital Marketing and entrepreneurship. IGI Global, pp 122-123.

8. Kuntsman A.A. Transformation of the internal and external business environment in the digital economy // Management of economic systems. - 2016 - No. 11 (93). - S. 1. (In Russian)

9. Nabyla Daidj. (2018) Uberization (or Uberification) of the Economy. Telecom Ecole de Management, France, IGI Global. 2354 p.

10. Popova I.V., Huseynova A.A. "Uberization" of the Russian economy: goal, disadvantages, advantages, prospects // Young researcher Don. - 2017. - No. 4 (7). - S. 165-168. (In Russian)

11. Rumyantseva Yu.V. Opportunities for the Uberization of the Russian Economy // In the collection: Strategies to counter threats to the economic security of Russia Materials of the All-Russian Scientific and Practical Conference. 2018. s. 242-247. (In Russian)

12. Schwab K. (2017). The Fourth Industrial Revolution. Penguin UK, pp. 16-75.

13. Schmidt E. (2015) How Google Works [translation from English] Moscow: Eksmo. (In Russian).

14. Marketplace for business [Electronic resource] URL: https://blog.sibirix.ru/2019/01/31/marketplaces/ (In Russian)

15. Q1 2019 e-commerce Russian market size [Electronic resource] URL: https://www.shopolog.ru/news/razmer-rossiyskogo-rynkaelektronnoy-torgovli-za-1-kvartal-2019-goda/ (In Russian)

16. Sklyarova E.E. Features of the development of an innovative economy and state innovation policy in Russia at the present stage. Novosibirsk: Center for the Development of Scientific Cooperation, 2015. 308 s. (In Russian) 